\title{
Two cases of Whipple's disease showing clinical and morphological similarity
}

\author{
H. Oliva, C. GONZÁlez CAMPOS, V. NAVARRO, AND H. H. MOGENA \\ From the Departments of Pathology and Gastroenterology, Jiménez Díaz Foundation, Free University, Madrid, \\ Spain
}

SUMMARY Twocases of Whipple's disease are reported in which a parallel course is confirmed between the clinical and ultrastructural findings. This is not so with light microscopy since it takes much longer for these findings to return to normal. In case 1 , the presence of bacilli circulating freely in the sinusoid of a lymph node is described. Case 2 demonstrates the existence of special granulomata formed by atypical macrophage histiocytes which appear in coagulative necrosis together with a closely adherent crown of lymphocytes. Furthermore, these histiocytes have moved towards the deepest part of the lamina propria, and have become dissociated from the muscularis mucosae causing a diverticulosis of the small intestine.

\section{Material and Methods}

Tables I and II illustrate the clinical and morphological similarity of the two cases, all the biopsy samples having been obtained from the jejunum with the Crosby capsule (Dr Miranda), and then examined with haematoxylin and eosin, PAS, Alcian Blue, and Gram stains. On one occasion the acid phosphatase method by Burnstone simultaneous mating (naphtol phosphate As-BI-Fast-Red-Videt LB) was used.

The electron microscope study was performed by

Received for publication 14 March 1972.

\begin{tabular}{|c|c|c|c|}
\hline Date & Clinical History & Light Microscopy & Electron Microscopy \\
\hline 1 March 1969 & $\begin{array}{l}\text { D.D.D., 42-year-old woman. } \\
\text { Arthralgia for four years. Fever for } \\
1 \text { year, colicky pains, day and night } \\
\text { diarrhoea with melaena which } \\
\text { necessitated a transfusion and loss } \\
\text { of } 10 \mathrm{~kg} \text { of weight. Anaemia, } \\
\text { leucocytosis. Faecal fat }=11 \mathrm{~g} \text { a day. }\end{array}$ & $\begin{array}{l}\text { Plurizonal villous atrophy. Great } \\
\text { number of macrophages with PAS } \\
\text { particles positive (P.P.M.) in the } \\
\text { entire thickness of the wall itself. } \\
\text { Fig. } 1 \text { Lymphadenitis with M.P.P. }\end{array}$ & $\begin{array}{l}\text { Whole bacilli in the interstices, } \\
\text { perivascular spaces, vascular } \\
\text { endothelia, and interior of the } \\
\text { macrophages. In this latter site, some } \\
\text { begin to degrade within granules. } \\
\text { Bacilli circulating in sinusoids of a } \\
\text { lymphatic ganglion. }\end{array}$ \\
\hline 1 May & $\begin{array}{l}\text { With aureomycin }(10 \mathrm{~g} / \text { day }), \text { fever, } \\
\text { anaemia, leucocytosis disappeared } \\
\text { and } 2 \mathrm{~kg} \text { weight gain }\end{array}$ & $\begin{array}{l}\text { The same picture but the villi are } \\
\text { somewhat more elongated. }\end{array}$ & $\begin{array}{l}\text { There are no whole bacilli. Lysosomic } \\
\text { granules with remains of changed } \\
\text { bacilli and others with 'fingerprint' } \\
\text { membranes. }\end{array}$ \\
\hline 1 July & $\begin{array}{l}\text { Same treatment. Good general } \\
\text { condition. Gained } 10 \mathrm{~kg} \text { weight. } \\
\text { Faecal fat } 2 \cdot 15 \mathrm{~g} / 24 \text { hours. Slight } \\
\text { anaemia. }\end{array}$ & Same picture & \\
\hline 1 Oct & $\begin{array}{l}\text { Same treatment. Good general con- } \\
\text { dition with one movement, } 5 \text { kg } \\
\text { weight gain, no anaemia, no leuco- } \\
\text { cytosis V.S. } 13 \text {. }\end{array}$ & $\begin{array}{l}\text { Mucosa returning to normal with } \\
\text { thinner and longer villi and less } \\
\text { M.P.P., leaving the vertices of the free } \\
\text { lamina propria and congregating next } \\
\text { to the glandular colla. }\end{array}$ & $\begin{array}{l}\text { No whole or residual form bacilli, } \\
\text { only granules of membranous } \\
\text { content. }\end{array}$ \\
\hline 1 Jan 1970 & $\begin{array}{l}\text { Same treatment. } 3 \mathrm{~kg} \text { weight gain } \\
\text { (total, } 20 \mathrm{~kg} \text { ). Normal blood formula } \\
\text { V.S. } 12 . \text { Normal disacharidases. }\end{array}$ & $\begin{array}{l}\text { Almost normal mucosa with few } \\
\text { PAS-positive macrophages. }\end{array}$ & \\
\hline 1 April & $\begin{array}{l}\text { Same treatment. Keeps on } \\
\text { improving clinically. }\end{array}$ & $\begin{array}{l}\text { Jejunal mucosa normal with some } \\
\text { isolated macrophages on muscularis } \\
\text { mucosae. }\end{array}$ & \\
\hline $1 \mathrm{Dec}$ & Completely cured. & & \\
\hline
\end{tabular}

Table I Summary of case 1 


\begin{tabular}{|c|c|c|c|}
\hline Date & Clinical History & Light Microscopy & Electron Microscopy \\
\hline 1 Nov 1962 & $\begin{array}{l}\text { A.J.F. 60-year-old man. Diarrhoea } \\
\text { (6-7), } 2 \text { years, Liquid stools, day } \\
\text { time, without blood, ceased } \\
\text { momentarily with treatment. } \\
\text { Asthenia, arthralgia, loss of } 10 \mathrm{~kg} \text {, } \\
\text { axillary adenopathy. Anaemia. } \\
\text { Leucocytosis. Resistent aquilia } \\
\text { histamine. Hypoproteinaemia. Faecal } \\
\text { fat } 45 \mathrm{~g} / \text { day. }\end{array}$ & $\begin{array}{l}\text { Mucosa changed with short and } \\
\text { wide villi. The entire wall full of } \\
\text { macrophages with PAS-positive } \\
\text { particles. }\end{array}$ & \\
\hline 1 Dec & $\begin{array}{l}\text { Phthalylsulphthiazole treatment. } \\
\text { Slight improvement, } 5 \mathrm{~kg} \text { weight gain }\end{array}$ & $\begin{array}{l}\text { The changes remain the same, lym- } \\
\text { phangiectasis appearing }\end{array}$ & $\begin{array}{l}\text { Numerous bacilli in the interstices and } \\
\text { around the amyelinic capillaries and } \\
\text { nerves, but not seen in epithelium or } \\
\text { endothelium. Within the macrophages, } \\
\text { lysosomic granules. with bacilli in } \\
\text { several phases of degradation. }\end{array}$ \\
\hline 1 June 1963 & $\begin{array}{l}\text { Treatment with aureomycin, } \\
\text { improvement accentuated. One } \\
\text { movement per day. Faecal fat } 3.51 \\
\text { g/day. }\end{array}$ & Same picture. & $\begin{array}{l}\text { There are no bacilli, neither whole } \\
\text { nor in decomposition. Granules } \\
\text { membranous or empty, but some } \\
\text { fused with autophagic vacuoles where } \\
\text { there are mitochondria. }\end{array}$ \\
\hline 1 Dec 1963 & $\begin{array}{l}\text { Clinically and biochemically well, } \\
\text { treated irregularly with aureomycin } \\
\text { Faecal fat } 4 \cdot 5 \mathrm{~g} / \text { day. Radio- } \\
\text { logically, hypotonia and changing } \\
\text { diverticula }\end{array}$ & $\begin{array}{l}\text { The villi become longer and thinner. } \\
\text { There are few macrophages near the } \\
\text { muscularis mucosae. }\end{array}$ & $\begin{array}{l}\text { There are no bacilli. Macrophages } \\
\text { with residual granules with hardly } \\
\text { any remaining membrane near the } \\
\text { muscularis mucosae. }\end{array}$ \\
\hline 1 Jan 1971 & $\begin{array}{l}\text { Subjectively well, with one soft } \\
\text { movement a day. Slight arthralgia. } \\
\text { Six months without treatment, no } \\
\text { anaemia V.S. } 26 \text {, faecal fat } 6 \mathrm{~g} / \text { day. } \\
\text { Enterobacter seen on intestinal biopsy } \\
\text { and diverticula more marked. }\end{array}$ & $\begin{array}{l}\text { Jejunal picture practically normal } \\
\text { with lymphohistiocytic granulomas } \\
\text { and few macrophages near the } \\
\text { muscularis mucosae. No } \\
\text { lymphangiectasia. }\end{array}$ & $\begin{array}{l}\text { Few and small macrophages with } \\
\text { granules without bacilli and } \\
\text { membranes and abundant lipidic } \\
\text { drops. Sometimes, pseudobacillar } \\
\text { bodies near the Golgi system. }\end{array}$ \\
\hline
\end{tabular}

Table II Summary of case 2

fixation with osmium tetroxide, inclusion in Vestopal $\mathrm{W}$, sectioning in the ultramicrotome LKB-III, and observation under a Tesla 242 microscope.

Biopsy 69B1140 was taken from a left inguinal lymph node.

\section{Results}

\section{LIGH'T MICROSCOPY}

The morphological evolution in both cases is shown in the corresponding Table. However, in the last biopsy peculiar granulomata can be observed, with their centres formed by a cell in coagulative necrosis, but no positive reaction to PAS. This means that it is difficult to recognize a spherical conglomerate inside the cytoplasm, to which a crown of lymphocytes adheres closely (Figs. 2 and 3). Two of these granulomata have been identified in six of the serial sections of a biopsy measuring $0.4 \mathrm{~cm}$. There are also macrophages with weakly PAS-positive particles in intimate contact with the cells of the muscularis mucosae (Fig. 4).

\section{ELECTRON MICROSCOPY}

Three intestinal biopsies and one node biopsy from case 1 were examined. The first study corresponds to specimen 239. There is nothing abnormal in the epithelium. On the wall itself, elongated structures stand out, showing the shape of bacilli from 2.5 to $3 \mu$ long and 0.2 to $0.4 \mu$ wide surrounded by a capsule $350 \AA$ thick. Inside the capsule small, intensely osmiophilic areas are observed, alternating with other light ones (Fig. 5). Practically all of them are inside the macrophages, but they seem to have been phagocytosed, except for a few which are beginning to be digested. Others appear inside the vascular endothelia. In biopsy no. 247 , there are no whole bacilli. Inside the macrophage histiocytes are replaced by granules of various sizes surrounded by a single membrane. Inside this membrane there is a series of fine membranes more or less parallel, and sometimes they form a small closed tube. Inside the granules certain elongated structures appear which are intensly osmiophilic and resemble bacilli in shape (Figs. 6 and 7). Other macrophages contain granules, inside of which neither of the two described structures remain.

Between the macrophages with both types of granules there are many lipid drops, small numbers of mitochondria and free ribosomes. Biopsy 267 shows neither bacilli nor any shape which resembles them. Biopsy 240, which corresponds to the lymph node, shows many extra- and intracellular bacilli, with the same characteristics as those described, and they can be observed dividing by partition (Fig. 8). 


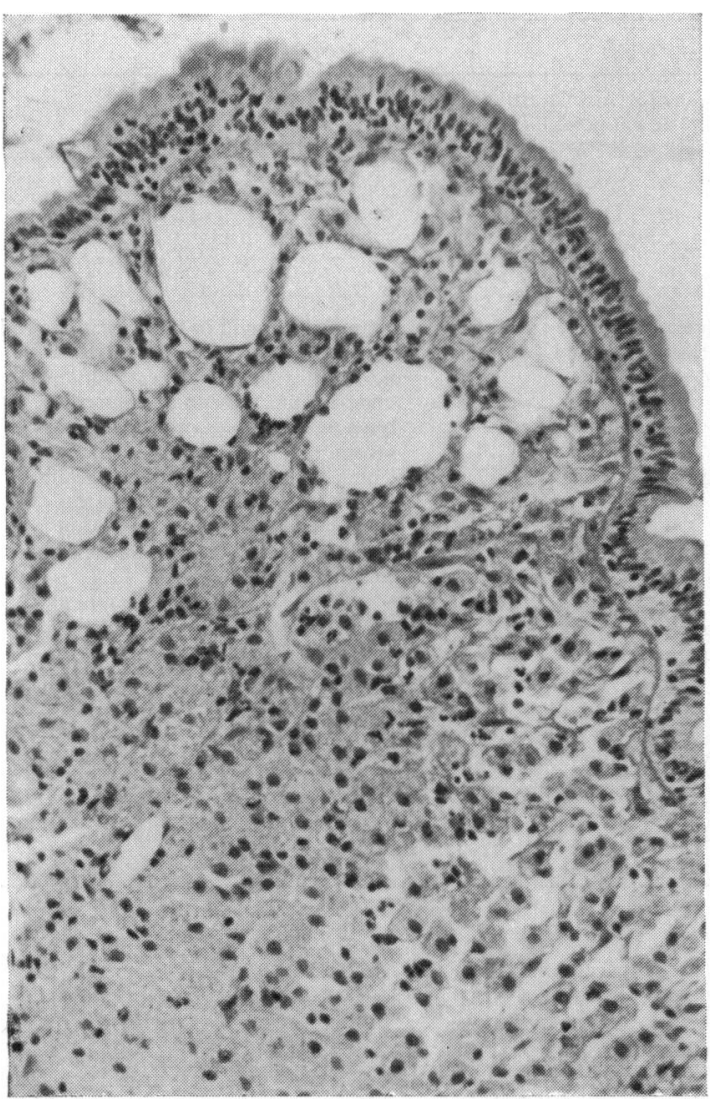

Fig. 1 Optical image of an intestinal villus with lymphangiectasia an the wide macrophages with granulous content. Haematoxylin and eosin.

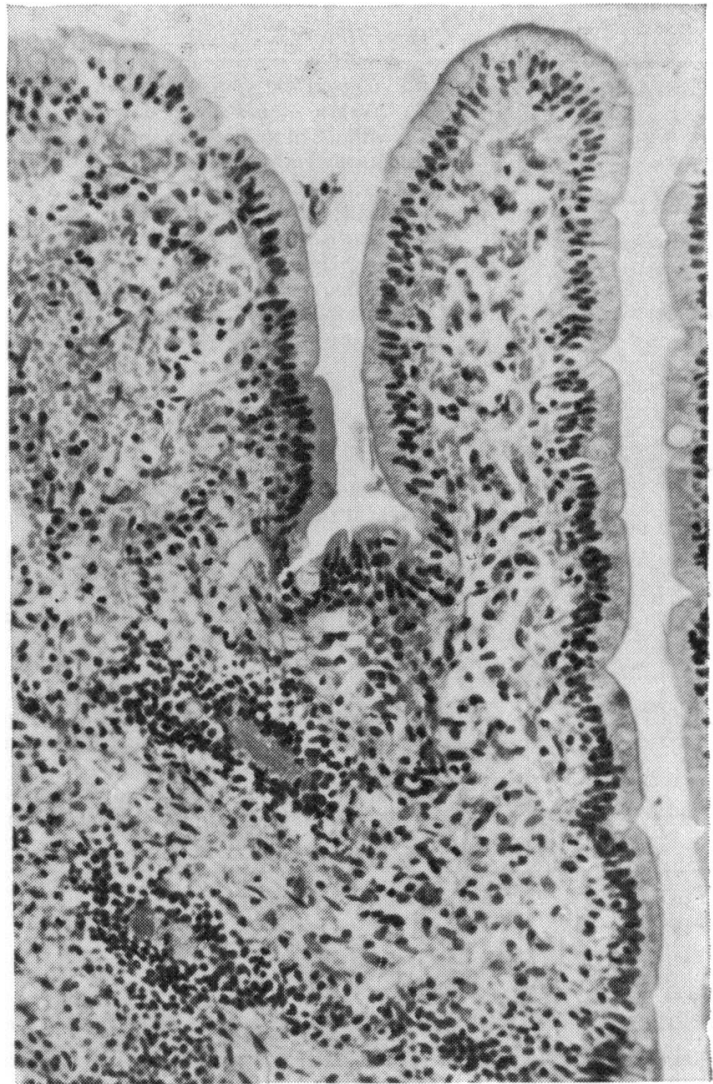

Fig. 2 After eight years' treatment and clinically cured, granulomas appear which could be 'specific' to this process. $H$ and $E$.

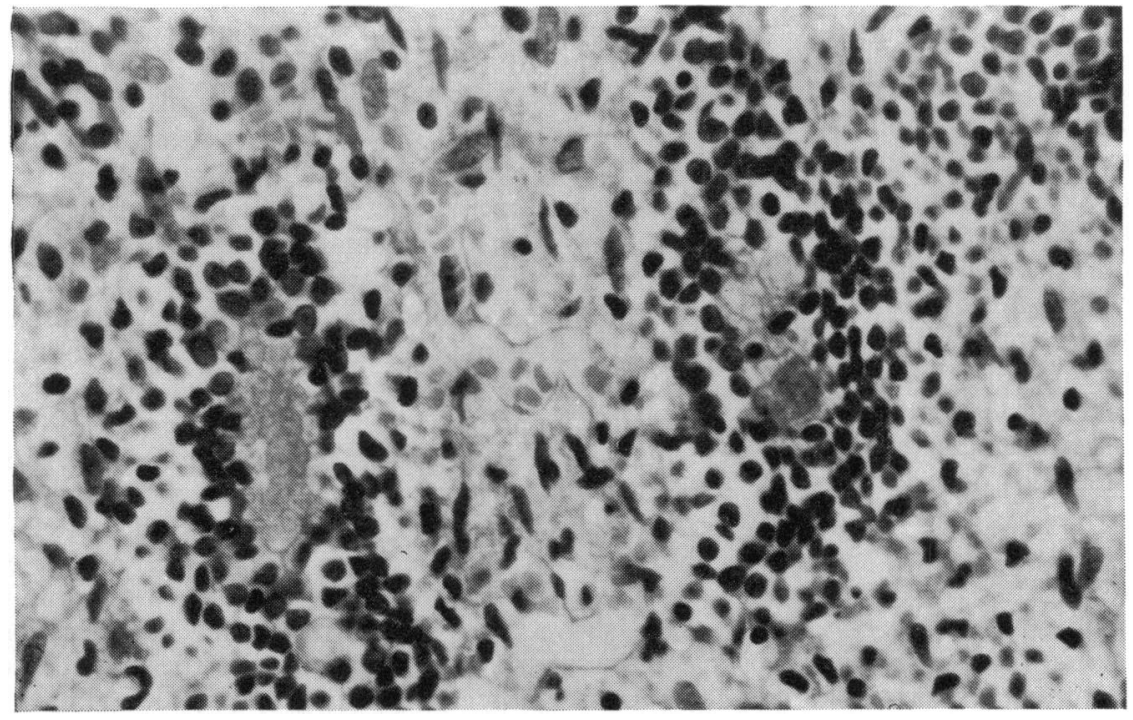

Fig. 3 The granulomas have a central necrotic cell which makes it possible to recognize cytoplasmatic granules surrounded by a crown of lymphocytes. $H$ and E. 


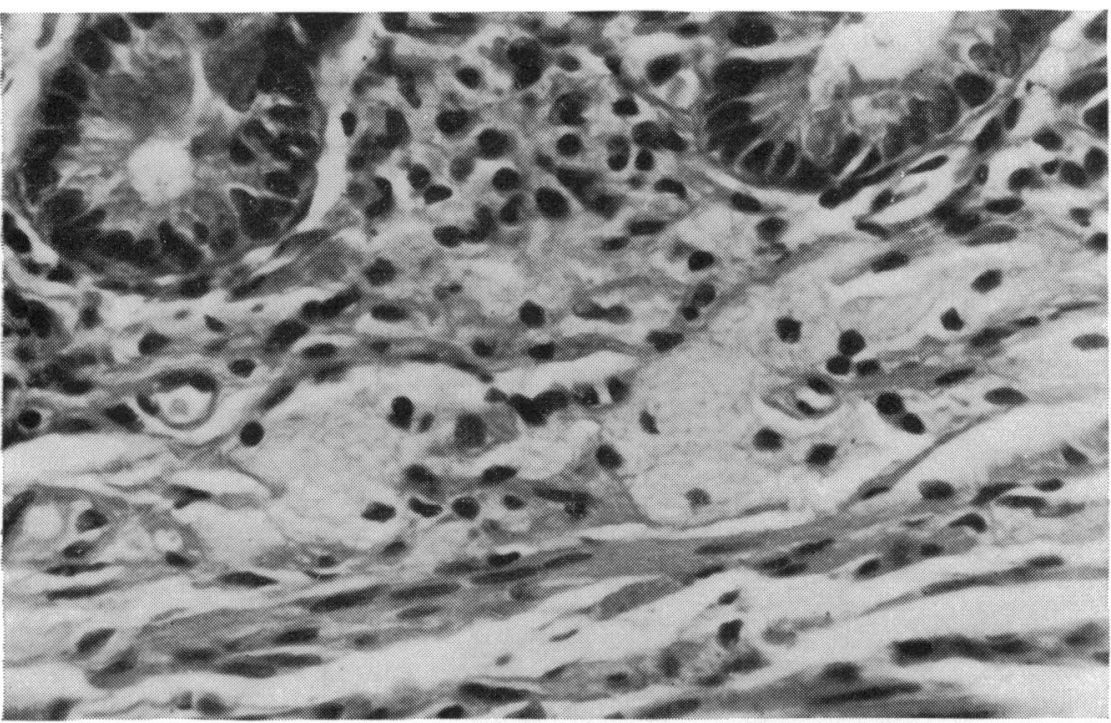

Fig. 4 Degenerating macrophages near the muscularis mucosae. $H$ and $E$.

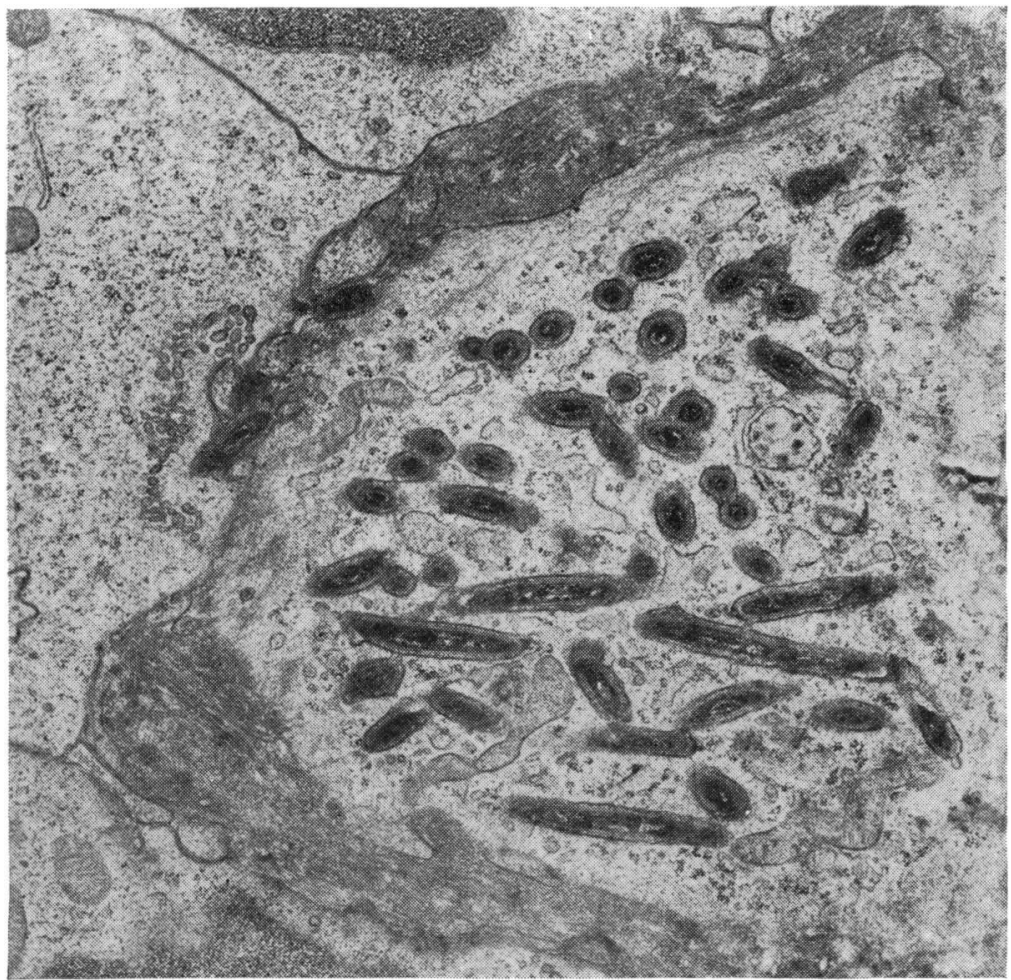

Fig. 5 Whole bacteria inside a macrophage $\times 18760$. 

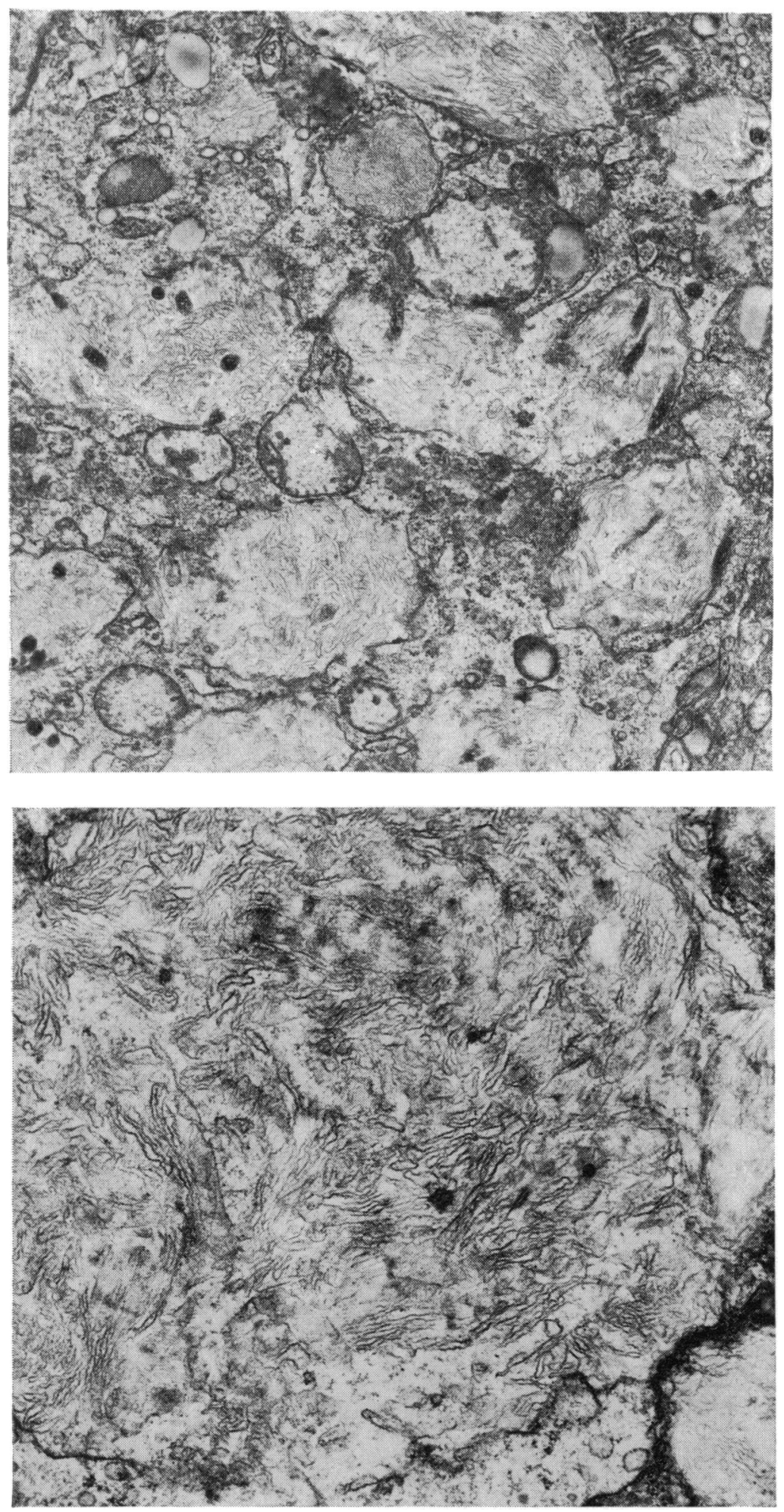

Fig. 6 Lysosomic granules filled with membranes and bacterial remains $\times 18760$.

Fig. 7 Granule with membranes without bacterial remains $\times 27500$. 

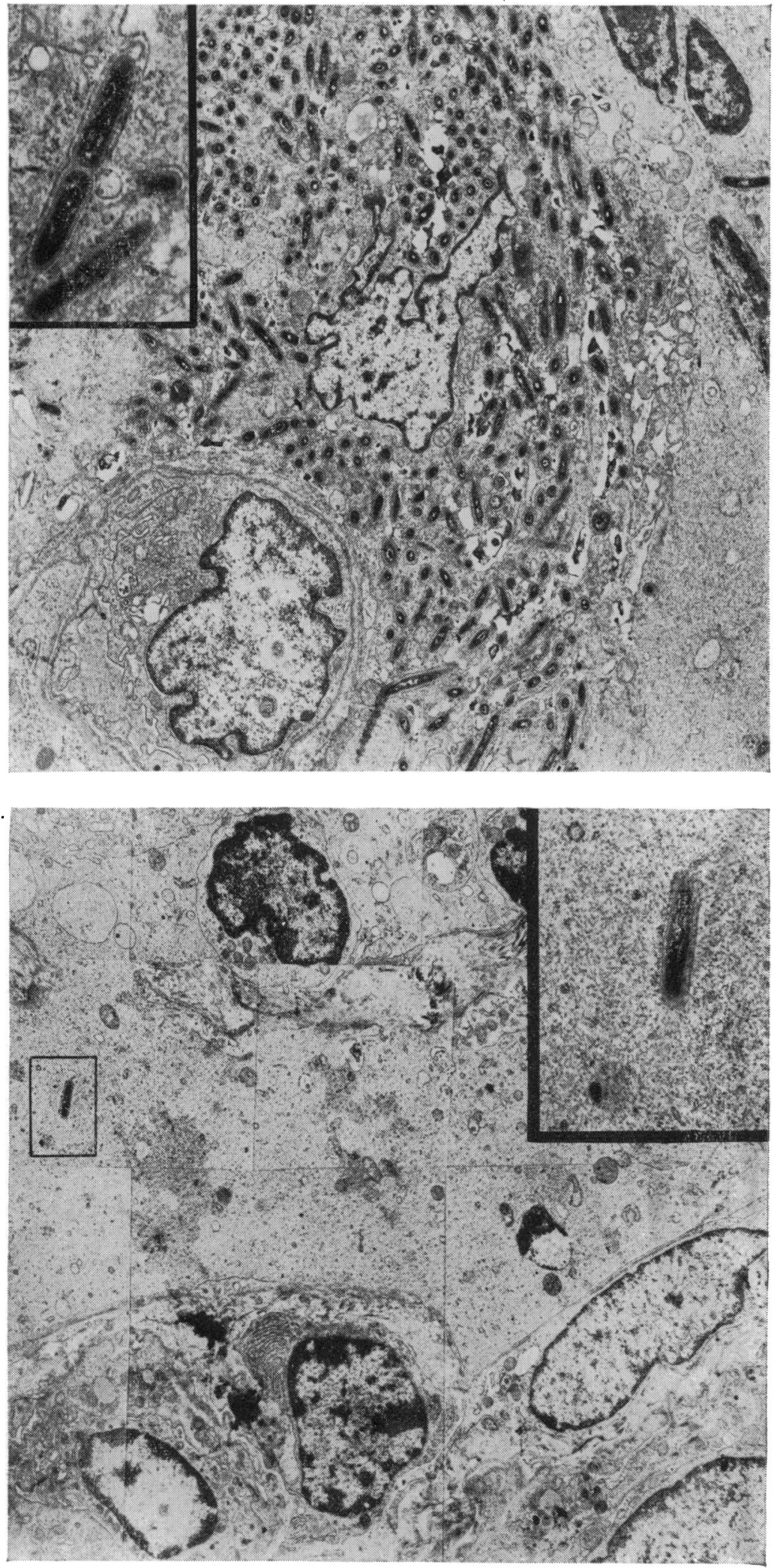

Fig. 8 Intracytoplasmic bacteria in a lymph node. In the inset dividing can be observed.

Fig. 9 Groin lymph node. Sinusoid with phagocytes, limiting cells, and fenestrations $(\rightarrow)$. In full light, a whole bacterium appears reduced from $\times 14300$. In the inset, the same bacterium more highly magnified showing that it has the same structure as those found in the intestinal mucosa $\times 28600$. 


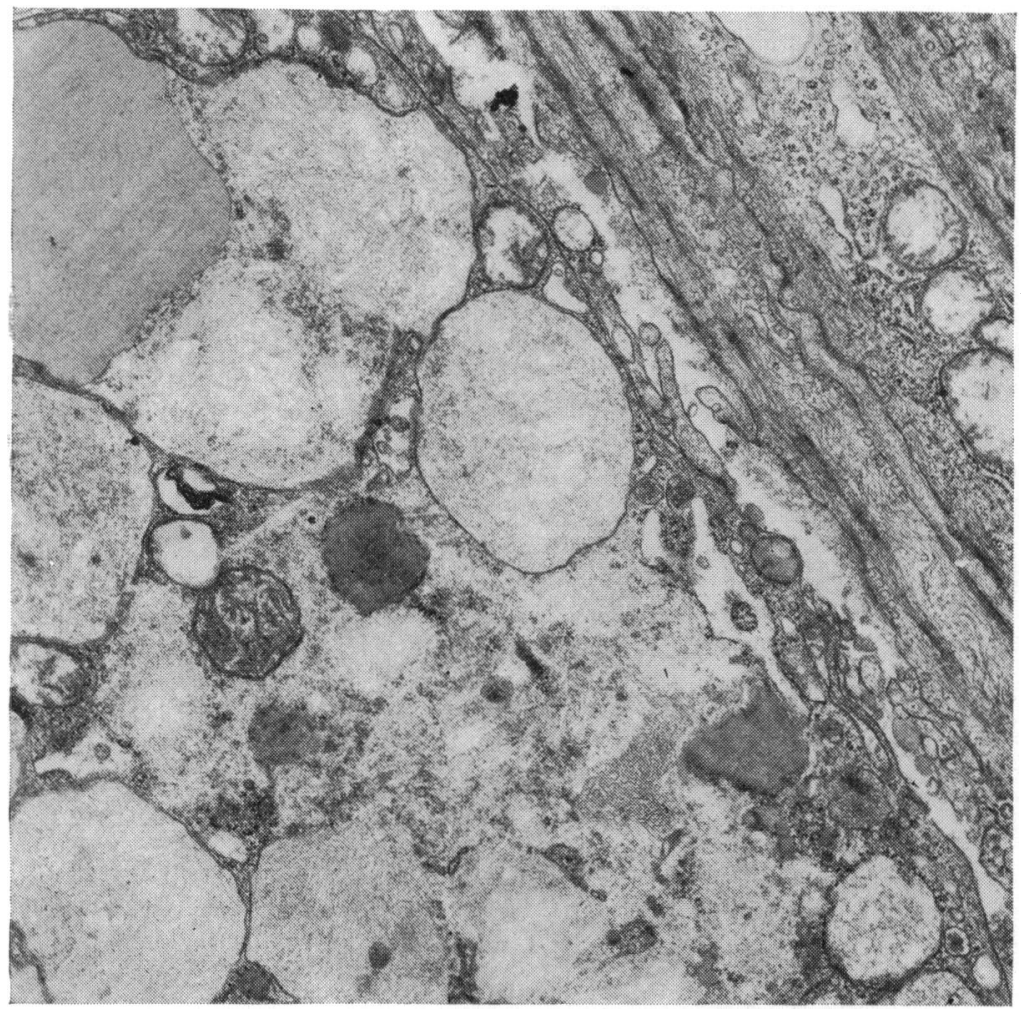

Fig. 10 Part of $a$ macrophage with almost empty granules close to smooth muscle cells.
Some whole bacilli circulate in the lumina of the lymphatic sinusoids (Fig. 9).

The electron microscopy results for case 2 can be seen in Table II. Biopsy 380 shows that the foamy cells described at the muscularis mucosae level are macrophage histiocytes with empty granules (Fig. 10).

\section{Discussion}

The peculiar nature of Whipple's disease is shown in the moderate response of the host. In the active phases small agglomerates of polymorphonuclear leucocytes can be seen, and, following antibiotic treatment, plasma cells, although always proportionately low. We have, however, been able to observe a granulomatous response in our case 2, not pointed out until now, of distinctive granulomata formed by a degenerating central cell, which we interpret as an atypical histiocyte, since spherules left over from the granular deposits can still be recognized in it. This cell provokes a response of round cells, predominantly lymphocytes, which are in intimate contact with it (peripoiesis). As usual, extra- and intracellular fat is found, as in lymphangiectasia.
These bacterial structures have already been considered by Cohen, Holt, and Isselbacher (1960) to be possibly of viral origin, and have been described by many workers since, including ourselves (Jiménez Díaz, Mogena, Valle, Oliva, and Navarro, 1964) and, following the development of these findings, by Hendrix and Yardley (1970) in their extensive review.

We believe that the bacteria may penetrate the intestinal membrane intermittently, and would explain why they are so seldom observed on the covering epithelium. Only Yardley and Hendrix (1961) and Dobbins and Ruffin (1967) have observed them. Some bacteria would be within the epithelial lysosomes and others would be able to pass through the basement membrane, appearing in the interstices of the 'lamina propria' rather than in the perivascular spaces, from which they can go in two directions. They can either be phagocytosed by the histiocytes or they can go through the basal lymph capillaries up to the lymph gland (Kojecký, Malinský, Kodousek, and Marśálek, 1964). In the lymphatics leading to the thoracic duct whole histiocytes or fractions of their cytoplasm can be seen (Spain and Kliot, 1962; Tesler, Witte, Becker, and Dumont, 1965). 
In the first instance, the bacilli induce an inflammatory response with a great abundance of histiocytes but a scarcity of other elements, such as polymorphonuclear leucocytes, which also phagocytose certain bacteria (Trier, Phelps, Eidelman, and Rubin, 1965). At first the bacteria appear untouched in the hyaloplasm of the macrophages, but are soon included in lysosomic granules, as we have been able to verify by their being rich in acid phosphatase. What we do not know is if these lysosomes have an enzymatic defect which, together with the bacteria, constitute an aetiological factor. Each lysosome may have several bacteria that undergo a degradation process which morphologically consists of the loss of their cellular wall and homogenization. Later on, these closed structures become linear, giving the granules an appearance of a meshwork or of a fingerprint. Finally, the granules lose every vestige of membrane and remain amorphous, empty but 'dirty'.

This evolution has been identical in both our cases and lasted two and six months respectively. Even with clinical improvement, a morphological residue still persists as granulomata or as macrophages which are mechanically displaced (due perhaps to the recuperation of the villous structure) until they reach the muscularis mucosae which halts them (Trier et al, 1965; Dobbins and Fuffin, 1967). This phenomenon, too, might have had a role in the production of diverticula in case 2 .

\section{References}

Caroli, J., Stralin, H., and Julien, C. (1963). Considérations thera- peutiques et pathogeniques sur la maladie de Whipple. II. Maladie de Whipple, maladie microbienne? Arch. Mal. Appar. dig., 52, 55-72.

Cohen, A. S., Schimmel, E. M., Holt, P. R., and Isselbacher, D. J. (1960). Ultrastructural abnormalities in Whipple's disease. Proc. Soc. exp. Biol. (N.Y.), 105, 411-414.

Chears. W.C., and Ashworth, C.T.(1961). Electron microscopic study of the intestinal mucosa in Whipple's disease. Gastroenterology, 41, 129-138.

Dobbins, W. O. III, and Fuffin, J. M. (1967). A light and electronmicroscopic study of bacterial invasion in Whipple's disease. Amer. J. Path., 51, 225-242.

Hendrix, T. R., and Yardley, J. H. (1970). Whipple's disease. In Modern Trends in Gastroenterology, 4, edited by W. I. Card and B. Creamer, pp. 229-251. Butterworths, London.

Jiménez Díaz, C., Mogena, H. G., Valle, A., Oliva, H., and Navarro, V. (1964). Estudio clínico, histológico y ultramicroscópico de un caso de enfermedad de Whipple, antes y después del tratamiento con aureomicina: contribución al conocimiento de la naturaleza de la enfermedad. Rev. Clin. Esp., 92, 229-242.

Kojecký. Z., Malinský, R., Kodousek, R., and Maršlek, E. (1964). Frequence of occurrence of microbes in the intestinal mucosa and in the lymph nodes during a long term observation of a patient suffering from Whipple's disease. Gastroenterologia, (Basel), 101, 163-172.

Kurtz, S. M., Davis, T. D., Jr., and Ruffin, J. M. (1962). Light and electron microscopic studies of Whipple's disease. Lab. Invest., 11, 653-665.

Pérez, V., Schapira, A., Pellegrino, A. I. de, Rybak, B. J., and Larrechea, I. de (1963). Light and electron-microscope findings on jejunal biopsy in Whipple's disease: studies before and after antibiotic therapy. Amer. J. dig. Dis., 8, 718-728.

Rostgaard, J. (1964). Bacteria in Whipple's disease: combined electron and light microscopy. Acta path. microbiol. scand., 60, 450-461.

Spain, D. M., and Kliot, D. A. (1962). P.A.S. and Sudan positive pulmonary emboli in Whipple's disease. Gastroenterology, 43, 202-205.

Tesler, M. A., Witte, M. H., Becker, F. F., and Dumont, A. E. (1965). Whipple's disease: identification of circulating Whipple cells in thoracic duct lymph. Gastroenterology, 48, 110-117.

Trier, J. S., Phelps, P. C., Eidelman, S., and Rubin, C. E. (1965). Whipple's disease: light and electron microscopic correlation of jejunal mucosa, histology with antibiotic treatment and clinical status. Gastroenterology, 48, 684-707.

Yardley, J. H., and Hendrix, T. R. (1961). Combined electron and light microscopy in Whipple's disease. Bull. Johns Hopkins Hosp., 109, 80-98. 